\title{
Financial Performance Analysis on Micro, Small, and Medium Enterprises of Cassava Product in Cibadak, Lebak Regency, Banten
}

\author{
Denis Mukarromah ${ }^{1^{*}}$, Jubaedah $^{2}$, Miguna Astuti $^{3}$ \\ ${ }_{1,2,3}$ Veteran National Development University of Jakarta, Indonesia \\ 1'denis.mh2016@outloook.com, 2jubaedah.nawir@gmail.com, ${ }^{3}$ miguna.astuti@upnvj.ac.id corresponding author
}

\begin{abstract}
There are indications of difficult capital access for MSMEs in Lebak. It is shown by Statistic Bureau (BPS) data in Banten Province that only 7.44\% of micro and small businesses in Banten obtain or apply for credit, or only $0.95 \%$ of Lebak micro and small businesses that can obtain or apply for credit. This research aims to determine the effect of (1) financial literacy on financial performance and (2) financial management on financial performance. This research is quantitative descriptive. The subjects were MSMEs of cassava processed products in Cibadak, Lebak Regency by distributing questionnaire to 86 samples. The data analysis technique used was descriptive analysis and inferential analysis with Partial Least Square (PLS). The results of this research show that (1) financial literacy has a positive effect on financial performance, and (2) financial management has a positive effect on financial performance.
\end{abstract}

Keywords: financial literacy, financial management, financial performance

\section{Analisis Kinerja Keuangan pada Pelaku UMKM Produk Olahan Singkong di Cibadak Kabupaten Lebak, Banten}

\begin{abstract}
Abstrak
Terdapat indikasi sulitnya akses permodalan pada UMKM di Lebak, Banten. Ditunjukan oleh data BPS Provinsi Banten bahwa hanya 7,44\% usaha mikro dan kecil di Banten yang memperoleh ataupun mengajukan kredit atau hanya $0,95 \%$ dari usaha mikro dan kecil Lebak yang dapat memperoleh atau mengajukan kredit. Penelitian ini bertujuan untuk mengetahui pengaruh (1) literasi keuangan terhadap kinerja keuangan, (2) pengelolaan keuangan terhadap kinerja keuangan. Bentuk penelitian ini adalah deskriptif kuantitatif. Subjek dalam penelitian ini adalah pelaku UMKM produk olahan Singkong di Cibadak, Kabupaten Lebak dengan penyebaran kuisioner pada 86 sampel. Teknik analisis data yang digunakan adalah analisis deskriptif dan analisis inferensial dengan Partial Least Square (PLS). Hasil penelitian ini menunjukan (1) literasi keuangan berpengaruh positif terhadap kinerja keuangan, dan (2) pengelolaan keuangan berpengaruh positif terhadap kinerja keuangan.
\end{abstract}

Kata kunci: literasi keuangan, pengelolaan keuangan, kinerja keuangan

\section{INTRODUCTION}

MSMEs (Micro, Small and Medium Enterprises) are the largest segment of national economic subjects. MSMEs have a strategic role for Indonesian economy includes being a major subject in economic activity on various sectors, providing large employment opportunities, developing local economic activities and empowering people, creating new markets and sources of innovation, and maintaining the balance of payments through export activities via the contribution they make (LPPI \& BI, 2015). MSMEs keep continue to experience significant growth each year. A total of 52 million MSME units in 2009 have increased to 64 million units in 2018. Lebak Regency, Banten is also a part of MSME growth each year. 
Lebak is an area in Banten Province with agriculture as its potential resource. Banten is a province whose existence is relatively new, but its territory is strategic because it is located at the entrance of Java from Sumatra and close to the Capital, Jakarta. The MSMEs in Lebak Regency experience a growth from 49,538 to 50,149 units and they contribute to the people economic growth in the area (Mansyur, 2018). The existence of MSMEs in Lebak is because they are supported by the ease of obtaining raw materials such as cassava, palm sugar, bamboo, melinjo (gnetum gnemon), and pandan (Alamsyah, 2016). To support the growth of MSMEs, optimization in coaching is always conducted by the Department of Cooperatives and SME of Lebak Regency to produce business clusters to overcome poverty (Hamzah, 2014). Coaching by the government such as product diversification, management, finance and entrepreneurship training. Banten Province's Statistic Bureau data indicates that only $7.44 \%$ of micro and small businesses in Banten that obtain or apply for credit or only $0.95 \%$ of Lebak micro and small businesses that obtain or apply for credit. The government has intensified its efforts to encourage the development of MSMEs, but MSMEs still experience difficulties in obtaining venture capital.

Financial performance is the achievement of results on a series of actions and decisions to achieve financial goals. There are three capital categories that contribute to business, they are financial capital, social capital, and human capita (Sanistasya et al., 2019). One of the consideration points so that the business can make a profit is by owning enough capital (Hatten, 2012). Capital optimization also helps businesses become more productive and develop. One way to obtain additional capital is by proposing capital to financial institutions. Based on the previous explanation, there are some indications of difficulty in accessing capital for MSMEs in Lebak. Deputy for Financing at the Ministry of Cooperatives and SME explains that the cause of SME financial access is not ideal, is due to the challenges of financial literacy (Jannah, 2015). Low financial literacy is hampered by many difficult banking terms. Ministry of Trade explains why the small percentage of SMEs do not obtain credit that is partly because the majority of SME financial management still do not separate personal finance from business finance (BPS, 2019).

The government has provided a lot of assistance to support MSME capital in Indonesia such as the People Business' Loan (KUR) program, the formation of cooperatives, or the provision of grants. However, one of the risks that must be considered in providing financing to MSMEs is that they do not have a good financial administration and management system, making it difficult for banks to find the information about their businesses completely (LPPI \& BI, 2015). MSMEs are often simple in managing their finances and weak in their control systems, making them vulnerable to fraud. The traditional management becomes a classic financial aspect for MSMEs which hinders the development of MSME itself (Subroto et al., 2016). MSMEs do not make evaluations of financial performance, and some even do not need to make financial reports because it is considered too complicated and a waste of time (Lia, 2015).

Several studies have indicated that MSMEs which apply financial literacy to higher level entrepreneurial activities have the opportunity to become more successful in running 
their businesses. Research of Sanistasya et al. (2019) indicates that financial literacy has a positive effect on the performance of small businesses in East Kalimantan. This research also explains that financial literacy can help business owners to obtain the necessary financial knowledge and skills. Research results that indicate a positive relationship between financial literacy and MSME business performance are also indicated by research of Aribawa (2016), Amri \& Iramani (2018), Lanang et al. (2014), Utomo \& Kajuan (2019), and Rahayu \& Musdholiah (2017). On the contrary, other research obtain results that financial literacy does not have effect on MSME growth. The research was conducted by C. E Eke \& Raath (2013) in the province of Gauteng, South Africa. Although it cannot obtain significant results between financial literacy and the growth of SME, the researchers explain that the research does not make a difference between SME owners who are not literate and SME owners who are not literate but employ people with financial literacy skills. Rahayu \& Musdholiah (2017) explain that the higher the level of financial literacy, business people can manage their business performance well so that it has long-term sustainability. Therefore, this research proposes a hypothesis, $\left(\mathrm{H}_{1}\right)$ Financial literacy has a positive effect on financial performance.

From many cases found, business failure starts from the mistakes made by management in managing their finances resulting in financial distress which remains unstoppable and ends with collapse (Asri, 2015). Similar to the financial management functions of large companies, MSMEs are also faced with financial decisions such as obtaining funds, funding and managing assets. Some external literature has provided mixed results on the effects of the relationship between financial management practices and SME performance in various settings. However, the literature in Indonesia rarely discusses financial management or financial management practices, mainly for MSMEs and specifically for MSMEs that engage in processed food products. Veeraraghavan (2018) indicates that financial management practices have a positive relationship with financial performance where the right financial decisions lead to improved financial performance. Bilal et al. (2017) in the results of research conducted on Spanish SME and Pakistani SME indicates that capital structure management and working capital management correlate significantly with financial performance. Optimal management of capital structure and working capital can create value for businesses to meet their business needs. Working capital management is crucial for business profitability but SMEs are often hampered by difficult financial access, the better the working capital management of SMEs, the lower the need for loans (Gorondutse et al., 2017). Meanwhile, Konak \& Güner (2018) find a negative effect of working capital management on profitability, which is an increase in the number of days in cash conversion cycle and short debt rotation that will reduce performance. Therefore, this research proposes a hypothesis, $\left(\mathrm{H}_{2}\right)$ Financial management has a positive effect on financial performance.

\section{Financial Performance}

Financial decision makers are often encountered with irrational considerations for making decisions. There is a bias in decision making under the condition of uncertainty (Shefrin, 2002). 
The business owners run a business to provide the goods or needed services. If they are unable to survive in business, they cannot meet the needs of goods and services to people. An entrepreneur is responsible for making a profit, it can be said that without profit a business does not contribute anything to society (Hatten, 2012). Profit is needed to (1) ensure that employees, creditors and suppliers can be paid; (2) maintain a strong competitive position; and (3) maintain efficient business operations.

"The business is expected actually to make a good profit." (Sigmon, 2010). In daily case business operations, there are circumstances such as cash flow difficulties, loss of profits, decreased sales, business competition, labor that needs to be increased, and sales that are too costly. These problems make profit as center of attention. Sigmon (2010) states that there are several steps to maximize business profitability including (1) changing the rules of operation, (2) staying visible and connected, (3) maximizing cash flow, (4) streamlining management costs, (5) raising the marketing, and (6) making everyone a salesperson.

Financial performance measurement in this research used non-performance measure to determine the representation of actions by MSME actors in producing financial performance.

\section{Financial Literacy}

In general, literacy is defined as the ability to read and write. UNESCO states that inequality is vulnerable to poverty (UNESCO, 2005). "One important element of literacy is economic literacy or financial literacy." (Soetiono \& Setiawan, 2018). By the existence of financial literacy, it is expected that the public can obtain financial welfare and produce high productivity. The OECD international institution uses three components to measure financial literacy, namely financial knowledge, financial behavior, and financial attitude. The public is expected to not only know and understand financial institutions, products or services. The public is also expected to have changes in financial attitudes and behavior to encourage financial goals, financial planning, financial decisions and better financial management.

\section{Financial Management}

"Financial management is an action to achieve financial goals in the future which includes personal financial management, family financial management, and corporate financial management."(Bank Indonesia, 2014).

"Financial management is known as one part of the science related to financial management to achieve certain goals."(Asri, 2015). Small businesses are relatively different from big businesses. Small businesses have limited resources where the functions and duties of a manager blend into one that is often performed by business owners. While the manager's function in large businesses has been sorted according to the company's structure and strategy. Financial management in business involves decision making related to the efficient use of financial resources in the production and sale of goods or services (Melicher $\&$ Norton, 2016). Decisions in financial management include investment decision, funding decision, and asset management decision (Kasmir, 2017). 
Asset management decision is related to the efficient management of assets, especially in the case of current assets and fixed assets (Kasmir, 2017). Good working capital management practices are likely to result in good manufacturing and marketing processes (Melicher \& Norton, 2016). Businesses that are unable to obtain the short-term funding are candidates for bankruptcy. The incompatibility between assets and funding sources and between cash in and cash out in working capital management make bankruptcy is likely to happen.

Funding decision is a decision relating to the amount of funds provided by the company, whether in the form of debt or own capital (Kasmir, 2017). The needed capital is usually used to purchase equipment, purchase inventory, pay salaries, and support sufficient cash in conducting business until income can support the needed cash flow. To meet the capital, people can use their own capital, ask for capital assistance from family or friends, offer family or friends with partial ownership position in the business, or obtain funding from the outside or venture capital (Melicher \& Norton, 2016).

The decisions with respect to investments are related to the number of owned assets, then the placement of the composition of each asset, for example how much is allocated for cash, fixed assets or other assets (Kasmir, 2017). Investment in assets provides the basis for business profitability (Vinturella \& Erickson, 2013). Investment in factories, infrastructure, equipment, and training can be used to provide products to sell, to generate profits, cash inflows, and increase company value.

\section{METHOD}

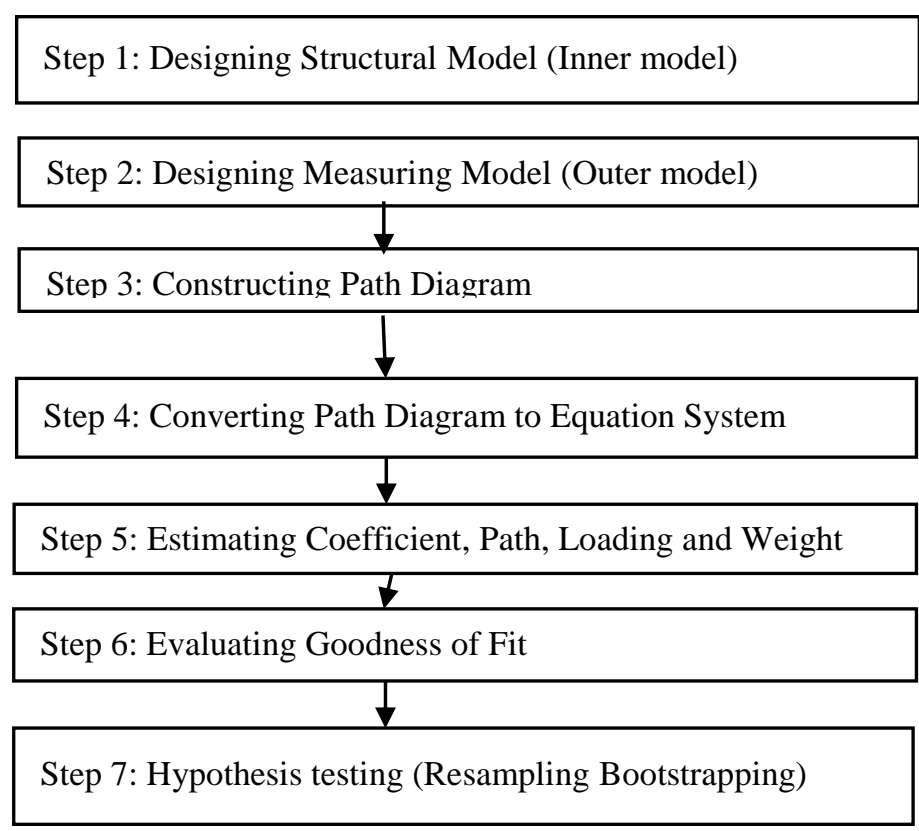

Figure 1. PLS Analysis Stages (Noor, 2014)

This research applied quantitative research method. Quantitative research method was used to examine specific populations or samples where the data collection used research instruments which then analyzed by using statistics to test the determined hypotheses (Sugiyono, 2017). Inferential analysis and descriptive statistical analysis were then used to 
analyze the data. Inferential analysis was used to make conclusions that applied to the population (Sugiyono, 2017). Inferential analysis in this research used structural equation (SEM) based on variance or PLS (partial least square) with the aim of predicting the effect of variable $\mathrm{X}$ on $\mathrm{Y}$. The stages of PLS structural equation analysis used in this research were as figure 1 .

Meanwhile Descriptive analysis was conducted to obtain descriptive illustration about the respondents in this research, specifically about the research variables used (Ferdinand, 2014). Descriptive analysis in this research used the index value with three box method. Index calculation of respondent's answer was conducted by the following formula (Ferdinand, 2014):

$$
\text { Index Value }(\% \mathrm{~F} 1 \mathrm{x} 1)+(\% \mathrm{~F} 2 \mathrm{x} 2)+(\% \mathrm{~F} 3 \mathrm{x} 3)+(\% \mathrm{~F} 4 \mathrm{x} 4)+(\% \mathrm{~F} 5 \mathrm{x} 5) / 5
$$

Data was obtained through primary sources that came from the first party who had a data (Abdillah \& Jogiyanto, 2015). The primary source in this research was the MSMEs of cassava processed products in Cibadak, Lebak Regency, Banten Province. The questionnaire was used to obtain primary data containing statements related to financial literacy, financial management, and financial performance. The questionnaire was distributed by using simple random sampling and obtained 86 samples with Yamane

Table 1. Research Indicator

\begin{tabular}{lll}
\hline \multicolumn{1}{c}{ Variable } & \multicolumn{1}{c}{ Dimension } & \multicolumn{1}{c}{ Indicator } \\
& $\begin{array}{l}\text { Changing operational } \\
\text { rules }\end{array}$ & $\begin{array}{l}\text { Increasing sales opportunities } \\
\text { Reducing Cost } \\
\text { Streamlining the administration }\end{array}$ \\
\cline { 2 - 3 } & Visible and connected & $\begin{array}{l}\text { Increasing credentials } \\
\text { Establishing affiliation }\end{array}$ \\
\cline { 2 - 3 } $\begin{array}{l}\text { Financial } \\
\text { Performance }\end{array}$ & Maximizing cash flow & $\begin{array}{l}\text { Maintaining cash flow } \\
\text { Managing budget } \\
\text { Working on its core }\end{array}$ \\
\cline { 2 - 3 } & Streamlining & $\begin{array}{l}\text { Changing office's focus } \\
\text { Creating a profit center }\end{array}$ \\
\cline { 2 - 3 } & management costs & $\begin{array}{l}\text { Developing a network } \\
\text { Covering all points } \\
\text { Developing a strategy }\end{array}$ \\
\cline { 2 - 3 } & Improving the marketing & $\begin{array}{l}\text { Obtaining a large support/power } \\
\text { Creating spells }\end{array}$ \\
\cline { 2 - 3 } $\begin{array}{l}\text { Financial } \\
\text { Literacy }\end{array}$ & salesperson & $\begin{array}{l}\text { Financial knowledge } \\
\text { Financial behavior } \\
\text { Financial attitude }\end{array}$ \\
\hline Financial & & $\begin{array}{l}\text { Investment Management } \\
\text { Capital structure management } \\
\text { Management }\end{array}$ \\
& & Working capital management \\
\hline
\end{tabular}

approach. The research indicators in the questionnaire were used to measure the research variables as follows: 


\section{RESULTS AND DISCUSSION}

MSME actors of cassava processed products in Cibadak, Lebak Regency, Banten were the object of this research. The specialization of MSME objects in cassava products is chosen to support local commodity products that produce national food security and revive the regional economy. This number is supported by the statistical results of Lebak area of 2018 that the agricultural sector and the trade sector have given most contribution to Lebak GDP. In addition, the growth of MSMEs in Lebak is partly due to the ease in obtaining raw materials such as cassava, pandan, palm sugar, bamboo, or melinjo (gnetum) (Alamsyah, 2016).

Respondent characteristics in this research was $74.42 \%$ dominated by women. It occurs because the products are generally made by housewives who sell their own products, distributed in small business, or being sold by the help of their husbands. They were dominated by elementary school/Islamic elementary school educational background by $53.49 \%$. Reasons for dropping out are mostly due to financial problems and the culture of early marriage. The objects were also dominated by respondents with age $>25-40$ years. In addition, Mekar Agung Village dominated the distribution of questionnaires from 15 villages in Cibadak Regency, Lebak.

Descriptive analysis by using the three-box method provides the following results:

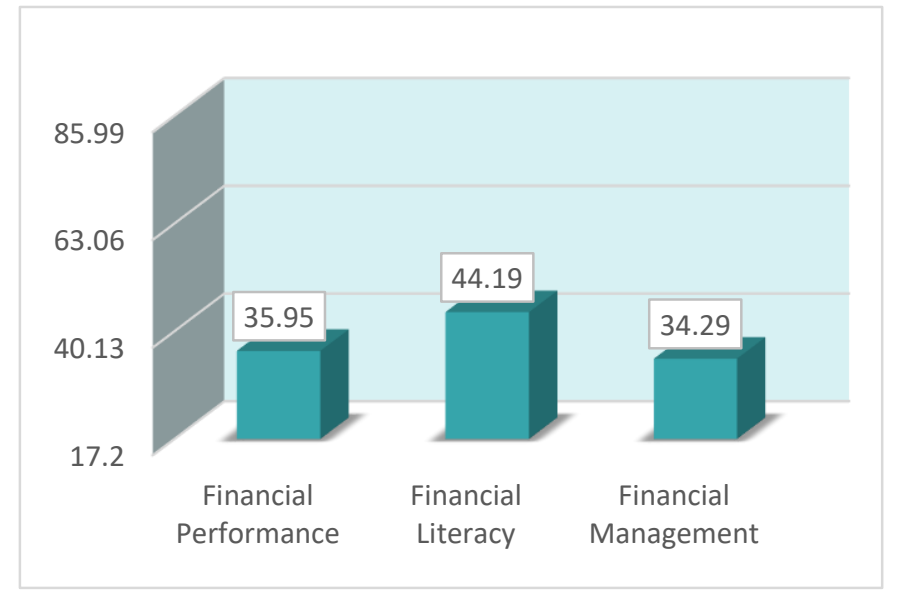

Table 2. Respondent's Answer Value Interpretation

\begin{tabular}{ll}
\hline Index Value & Interpretation \\
\hline $17.2-40.13$ & Low \\
$40.14-63.07$ & Moderate \\
$63.08-86$ & High \\
\hline
\end{tabular}

Figure 2. Respondents' Answers Interpretation

The results of the respondents' answers to the given statements were as follows: (1) Overall, the respondents' answers to the statements in the financial literacy variable were moderate value. It occurred because the overall index average of 44.19 was in the range of moderate values in the three-box method as a reference for assessment. Based on the results of the interview, most of the MSME had saved their money. However, the savings activities were neither long-term oriented nor profit-seeking. It occurred because MSMEs in Cibadak stated that their income was below-average generally, so, it was only sufficient for their daily needs. They generally also had not saved at financial institutions and only saved to their neighbors who provided savings and loan services or children's school savings. (2) Overall, the respondents' answers to the statements in the financial management variable were classified as low with an index value of 34.29. Based on the answers, generally, MSMEs in Cibadak had not made short-term or long-term investments because the earned profits were 
prioritized to meet daily needs or children's education. In terms of business funding, MSMEs in Cibadak only took advantage of the private sector and had not accessed the credit yet. Most MSMEs urged that they were reluctant to access credit because they were afraid of financial distress. MSMEs in Cibadak also did not plan or record supplies. Generally, they did not know how to record because they had never received training about recording. Meanwhile, the MSME actors had who received training in recording did not apply it because they think it was complicated.

Inferential analysis by using structural equations with PLS was used to predict the effect among variables. The instrument appropriateness in this research was using the Goodness of Fit evaluation. Goodness of fit evaluation in this research was seen from the validity and reliability tests as follows:

Table 3. Results of Validity and Reliability

\begin{tabular}{lrrr}
\hline \multicolumn{1}{c}{ Variable } & $\begin{array}{c}\text { Average Variance } \\
\text { Extracted (AVE) }\end{array}$ & $\begin{array}{c}\text { Composite } \\
\text { Reliability }\end{array}$ & $\begin{array}{c}\text { Cronbach's } \\
\text { Alpha }\end{array}$ \\
\hline Financial Performance $(\mathrm{Y})$ & 0.558 & 0.968 & 0.965 \\
Financial Literacy $\left(\mathrm{X}_{1}\right)$ & 0.505 & 0.945 & 0.938 \\
Financial Management $\left(\mathrm{X}_{2}\right)$ & 0.500 & 0.898 & 0.875 \\
\hline
\end{tabular}

The validity testing can be seen through the AVE value. The variable of financial performance, financial literacy, and financial management had an AVE value greater than 0.5 . These results declared that the instrument had been able to provide an appropriate measurement for the tested variable.

Furthermore, to determine the accurate consistent, and appropriate instrument testing, then the researchers conducted reliability test. The reliability test was shown through the Composite Reliability and Cronbach's Alpha results. Based on the table above, all constructs had a value greater than 0.7. The construct in this research had respondent's consistency and stability in answering the questionnaire or had good reliability.

The bootstrap method was used to determine the effect among variables in testing with PLS. This method used T-statistic which allowed the data to distribute freely, did not require the assumption of normal distribution, and did not require large sample. The hypothesis was supported if the T-statistic result was greater than the T-table. The t-table of 86 respondents with a significance value $<0.05$ was 1.663 . The following was the results of hypothesis testing:

Table 4. T-Statistic Test

\begin{tabular}{lccrr}
\hline \multicolumn{2}{c}{ Relationship Between Variabel } & $\begin{array}{c}\text { Original } \\
\text { Sample } \\
(\mathrm{O})\end{array}$ & T-statistic & P-value \\
\cline { 1 - 4 } Independent Variables & Dependend Variables & 0.260 & 2.766 & 0.006 \\
\hline Financial Literacy & Financial Performance & 0.702 & 7.687 & 0.000 \\
\hline
\end{tabular}

Hypothesis testing indicated that financial literacy had the value of $t_{\text {statistic }} 2.766>t_{\text {table }}$ 1.663. A positive relationship with financial performance was seen from the results of the original sample of +0.260 with a significance of the P-value of $0.006<$ alpha 0.05 . So, 
financial literacy had a positive effect on financial performance, in other words $\mathrm{H}_{1}$ was accepted.

Hypothesis testing indicated that financial management had value of $t_{\text {statistic }} 7.687>t$ table 1.663. A positive relationship with financial performance was seen from the results of the original sample of +0.260 with a significance of the $\mathrm{P}$-value of $0.006<$ alpha 0.05 . So, financial management had a positive effect on financial performance, in other words $\mathrm{H}_{2}$ was accepted.

\section{Effect of Financial Literacy on Financial Performance}

The results of outer loading on the financial literacy variable with large value are the manifest variables of FL3, FL10 and FL19. These large-value manifest variables have a major effect on the research results, in which financial literacy has a positive effect on financial performance. These large-value manifest variables indicate the importance of knowledge of savings and credit products, saving behavior, and saving attitudes for MSMEs in Cibadak.

Results of this research support several previous research that financial literacy affects the performance of MSMEs conducted by Humaira \& Sagoro (2018), Sanistasya et al. (2019), Utomo \& Kajuan (2019). If MSMEs are familiar with the features, benefits and risks; rights and obligations regarding financial services and products; as well as having skills in using financial products and services, it is going to direct them to the directed decisions on business performance. In addition, with good financial literacy, MSMEs are able to implement strategic plans to identify opportunities or threats and they can have an adequate financial access.

\section{Effect of Financial Management on Financial Performance}

The results of outer loading on financial management variables with large value are the FM8 and FM11. These large-value manifest variables have a major effect on the research results, in which financial management has a positive effect on financial performance. These high-value manifest variables indicate that there is no credit for increasing business capital and the use of business capital is only for building a business, not for personal needs. So, the MSMEs need more effective capital structure management and working capital management to improve their business financial performance.

Result of this research support previous research by Veeraraghavan (2018), Bilal, Naveed, \& Anwar (2017). Good financial management might create value for a business through effective investment management, capital structure management and capital management. The right investment decisions in placing funds in activities that provide more results for the business are needed in managing business investment. In terms of capital structure, sufficient capital is needed to finance business activities, while in terms of working capital management, effective management is needed, so that the business productivity is maintained and even increases. 


\section{CONCLUSION}

The results indicate that 1) financial literacy has a positive and significant effect on the financial performance of MSMEs in Cibadak and 2) financial management has a positive and significant effect on the financial performance of MSMEs in Cibadak.

The results of this research can be used as information for decision making to encourage the sustainability of MSMEs, mainly in Cibadak. The government as a regulator should make policies for equal financial access such as providing support services in the form of assistance programs, business development programs, and technology commercialization programs. It is expected that the service will actively cover all villages, because it indicates that the support services in the villages among Cibadak are not optimal. For instance, the remote villages from the center of the crowd never receive training programs and lack of assistance. Academics as educators can also provide empowerment regarding business managerial, financial literacy, and technology applications. These three problems are the important core to encourage the economic development of MSMEs in Cibadak. To obtain better financial access, the academics can also provide assistance such as calculating the required capital and preparing funding proposals to the funding institutions.

Then, for further research, the researchers suggest a model development to test the relationship between variables as a whole and/or add indicators to provide broader results regarding the factors affecting the financial performance of MSMEs.

\section{ACKNOWLEDGEMENT}

The researchers would like to show a gratitude for the research funding assistance to PT Indofood Sukses Makmur Tbk through Indofood Nugraha Research Program (IRN) $2019 / 2020$. It is expected that this research will be useful for the development of local commodity-based businesses and other forms of business development to support national economic welfare.

\section{REFERENCES}

Abdillah, W., \& Jogiyanto. (2015). Partial Least Square (PLS) Alternatif SEM dalam Penelitian Bisnis. Yogyakarta: ANDI OFFSET.

Alamsyah, I. E. (2016). UMKM Lebak Serap 89.346 Tenaga Kerja. Retrieved from https://republika.co.id/berita/koran/kreatipreneur/16/09/23/odybs211-umkmlebak-serap-89346-tenaga-kerja

Amri, A. F., \& Iramani, I. (2018). Pengaruh Literasi Keuangan Terhadap Kinerja Umkm Di Surabaya. Journal of Business \& Banking, 8(1), 59-70.

Aribawa, D. (2016). Pengaruh Literasi Keuangan terhadap Kinerja dan Keberlangsungan UMKM di Jawa Tengah. Jurnal Siasat Bisnis, 20 No. 1.

Asri, M. (2015). Keuangan Keperilakuan (Pertama). Yogyakarta: BPFE.

Bank Indonesia. (2014). Pengelolaan Keuangan. Modul Pelatihan, 17-18. 
Bilal, A. R., Naveed, M., \& Anwar, F. (2017). Linking distinctive management competencies to SMEs' growth decisions. Studies in Economics and Finance, 35, 13.

BPS. (2019). Analisis Hasil SE2016 Lanjutan, Potensi Peningkatan Kinerja Usaha Mikro Kecil (BPS, ed.). Badan Pusat Statistik.

C. E Eke, E., \& Raath, C. (2013). SMME Owners' financial literacy and business growth. Mediterranean Journal of Social Sciences, 4(13), 397-406.

Ferdinand, A. (2014). Metode Penelitian Manajemen (5th ed.). Semarang: UNDIP PRESS.

Gorondutse, A. H., Ali, R. A., Abubakar, A., \& Naalah, M. N. I. (2017). The Effect of Working Capital Management om SMEs Profitability in Malaysia. Polish Journal of Management Studies, 16(2), 99-109.

Hamzah, Z. Al. (2014). Pengusaha UMKM di Lebak Meningkat. Retrieved from https://www.republika.co.id/berita/koran/kreatipreneur/14/06/13/n73ck72pengusaha-umkm-di-lebak-meningkat

Hatten, T. S. (2012). Small Business Management Entrepreneurship and Beyond (5th ed.). Mason: South-Western Cengage Learning.

Humaira, I., \& Sagoro, E. M. (2018). Pengaruh Pengetahuan Keuangan, Sikap Keuangan, Dan Kepribadian Terhadap Perilaku Manajemen Keuangan Pada Pelaku Umkm Sentra Kerajinan Batik Kabupaten Bantul. Nominal, Barometer Riset Akuntansi Dan Manajemen, 7 No. 1.

Jannah, K. M. (2015). Tiga Penyebab UMKM Sulit Dapat Kredit dari Bank. Retrieved from https://economy.okezone.com/read/2015/06/15/457/1165615/tiga-penyebabumkm-sulit-dapat-kredit-dari-bank

Kasmir. (2017). Pengantar Manajemen Keuangan (Edisi Kedu). Jakarta: Kencana.

Konak, F., \& Güner, E. N. (2018). The Impact of Working Capital Management on Firm Performance : An The Impact of Working Capital Management on Firm Performance : An Empirical Evidence from the BIST SME Industrial Index. International Journal of Trade, Economic and Finance, 7 (2)(April 2016).

Lanang, I. P. E. S., Kirya, I. K., \& Cipta, I. W. (2014). Analisis Faktor-Faktor Yang Mempengaruhi Kinerja Usaha Mikro Kecil Dan Menengah (UMKM) Di Kabupaten Bangli. E-Journal Bisma Universitas Pendidikan Ganesha, 2(1), 11-21.

Lia, D. A. Z. (2015). Penilaian Kinerja Keuangan pada Usaha Kecil dan Menengah (UKM) Berdasarkan Analisis Rasio Keuangan. Jurnal Administrasi Bisnis, 25 No.1.

LPPI, \& BI. (2015). Profil Bisnis Usaha Mikro, Kecil dan Menengah (UMKM). LPPI dengan BI.

Mansyur. (2018). Pelaku UMKM Di Kabupaten Lebak Capai 50.149. Antaranews.Com. Retrieved from https://banten.antaranews.com/berita/31640/pelaku-umkm-dikabupaten-lebak-capai-50149

Melicher, R. W., \& Norton, E. A. (2016). Introduction To Finance (16th ed.). New Jersey: 
Jurnal Economia, 16(2), October 2020, 257-268

John Wiley \& Sons, Inc.

Noor, J. (2014). Analisis Data Penelitian Ekonomi \& Manajemen. Jakarta: GRASINDO.

Rahayu, A. Y., \& Musdholiah. (2017). Pengaruh Literasi Keuangan Terhadap Kinerja Dan Keberlanjutan Umkm Di Kota Surabaya. Jurnal Ilmu Manajemen (JIM), 5(3).

Sanistasya, P. A., Raharjo, K., \& Iqbal, M. (2019). The Effect of Financial Literacy and Financial Inclusion on Small Enterprises Performance in East Kalimantan. Jurnal Economia, 15(1), 48-59.

Shefrin, H. (2002). Beyond Greed and Fear Understanding Behavioral Finance and The Psychology of Investing. New York: Oxford University Press.

Sigmon, P. (2010). Six Steps To Creating Profit. New Jersey: John Wiley \& Sons Inc.

Soetiono, K. S., \& Setiawan, C. (2018). Literasi dan Inklusi Keuangan Indonesia (1st ed.). Depok: Rajawali Pers.

Subroto, S., Hapsari, I. M., \& Astutie, Y. P. (2016). Analisis Faktor-faktor yang Mempengaruhi Kinerja Usaha Mikro Kecil dan Menengah (UMKM) Kabupaten Brebes. Prosiding SNaPP2016 Sosial, Ekonomi, Dan Humaniora, 337-344.

Sugiyono. (2017). Metode Penelitian Kuantitatif, Kualitatif, dan R\&D. Bandung: Penerbit Alfabeta.

UNESCO. (2005). Education For All: Literacy for Life, Education for All Global Monitoring Report.

Utomo, M. N., \& Kajuan. (2019). Peran Literasi Keuangan dalam Meningkatkan Kinerja UKM di Kota Tarakan. Jurnal Manajemen Indonesia, 19(2), 139-148.

Veeraraghavan, K. (2018). Effect of Financial Management Practices on Financial Performance of Small and Medium Enterprises in Pudhucherry, India. International Journal of Management Studies, V(4(8)), 51.

Vinturella, J. B., \& Erickson, S. M. (2013). Raising Entrepreneurial Capital (2nd ed.). London: Elsevier. 